\title{
Storage properties and quality of meats deboned by different methods
}

\author{
L. RIIHONEN, J. LAINE and T. KÄRKKÄINEN \\ Finnish Meat Research Centre, Box 56, \\ SF-13101 Hämeenlinna, Finland
}

\begin{abstract}
The storage properties of mechanically deboned beef and pork were studied at storage temperatures of $+4^{\circ} \mathrm{C}$ for up to 6 days and at $-24^{\circ} \mathrm{C}$ for up to 140 days. Two types of machines were used for the separation of the meat, a pressure-based Inject Star machine (6 test series) and a Poss prototype machine based on scraping ( 2 test series). The samples were recovered using a disinfected machine and were immediately packaged in cartons and periodically analysed for their chemical, microbiological and physical characteristics. The beef samples maintained their overall quality better than the pork samples both in cold and frozen storage. The differences $(\mathrm{P}<0.05)$ between the samples recovered using the two machine types were reflected in the contents of ash, calcium, phosphate, microbes and dry matter.
\end{abstract}

Index words: mechanically deboned meat (MDM), quality of MDM, storage properties of MDM

\section{Introduction}

Mechanical deboning is more economical than hand boning because almost all of the meat can thus be recovered and used in meat products. The machines can handle either chopped bones or bones precleaned with a knife to varying stages.

Mechanically deboned meat differs from other meats primarily in its content of substances originating from bones and bone marrow, e.g. calcium, phosphorus, fluorine and iron. According to most studies, these substances are of benefit rather than a disadvantage to the meat industry $(1,2)$.
GoldSTRAND (3) reported that the protein content of meat separated from the neck bones of a pig was $14.2-15.1 \%$, the fat content was $24.7-29.9 \%$ and the moisture $53.7-$ $60.3 \%$. Meat mechanically separated from the bones of a low-fat bull contained a high content of protein $(16-17 \%)$ and only little fat $(9.9-24.4 \%)$ whereas meat separated from ham bones contained $10.0 \%$ protein, $42.3 \%$ fat and $44.6 \%$ moisture. These results are rather similar to those published by FIELD et al. (4) from which it can be calculated that the highest protein contents are in meat separated 
from the sow loin bones $(14.01 \%)$, veal frame bones $(17.57 \%)$, veal backbones $(15.98 \%)$ and bull's neck bones (17.18\%). The highest fat contents were in meat separated from blade bones $(42.37 \%)$ and thigh bones $(41.89 \%)$.

The mean calcium content of bones of varying ages and derived from different animal species and anatomical sites is about $37 \%$ of the ash content of the bones (5). When the deboning is based on scraping, calcium separation from the bones is more efficient than that achieved using other machine types.

Mechanically deboned meat contains small amounts of bone particles, the size and quantity of which depend on the machine used and the perforation size and the condition of its strainers (6). The bones of older animals contain more calcium and are therefore harder than the bones of younger animals $(7,8)$.

According to FIELD (9) the bone content is $0.05-0.31 \%$ in meat deboned by hand from pork head and neck bones.

The quality of meat can be estimated very well by its content of microbes. In practice the meat is unfit for human consumption if the number of bacteria is more than $1.0 \times 10^{8}$ $\mathrm{cfu} / \mathrm{cm}^{2}$ on the surface, or $0.5-1.0 \times 10^{8}$ $\mathrm{cfu} / \mathrm{g}$ inside the meat. If the microbial count is $1.0 \times 10^{7} \mathrm{cfu} / \mathrm{g}$, the meat is of poor quality $(10,11)$.

The $\mathrm{pH}$ value of meat has a great influence on microbial quality. If the $\mathrm{pH}$ of fresh meat is higher than 6.0 , its storage properties deteriorate; when the $\mathrm{pH}$ is 6.5 , the meat is of questionable quality. Moreover, this $\mathrm{pH}$ criterion cannot be directly applied to mechanically deboned meat because of the bone marrow released during separation, which may increase the $\mathrm{pH}$ up to 6.6. Thus, $\mathrm{pH}$ is not the only indication of microbiological deterioration of mechanically deboned meat, even though high $\mathrm{pH}$ values improve the growing conditions of microbes (4). High $\mathrm{pH}$ also limits the shelf life of mechanically deboned meat, implying that it should be used or frozen as quickly as possible after deboning.

The aim of this investigation was to evaluate factors, the quality, storage properties and usage restrictions of mechanically deboned meat. The amount of bone matter getting into meat in mechanical deboning was also analysed. Process variables were; machine type, animal species, fat content of MDM, frozen storage period, packaging material.

\section{Marerials and Methods}

\section{Samples}

The origin of bone, sample coding and the temperature after mechanical separation are presented in Table 1. In the sample codes B stands for beef, I for Inject Star deboner and the first $\mathrm{P}$ stands for pork and the second $\mathrm{P}$ for Poss deboner. Thus samples BI1, BI2.. (mechanically deboned beef) and samples PI1, PI2.. (mechanically deboned pork) were recovered using the Inject Star machine and samples BP and PP using the Poss machine. The temperature of bones to be processed was $+6^{\circ} \mathrm{C}$, the freezing temperature $-40^{\circ} \mathrm{C}$, utilization of freezing air $98000 \mathrm{~m}^{3} / \mathrm{h}$ in $6900 \mathrm{~m}^{3}$, and the temperature of frozen storage $-24^{\circ} \mathrm{C}$.

The temperature of the meat was measured immediately after mechanical separation, which happened next morning after cutting except aged bones after 72 hours.

\section{Experimental Procedure and Equipment}

The investigation was carried out partly at the production plant Osuusterastamo Kar-

Table 1. Materials used for mechanical deboning. Samples BI (MDB) and PI (MDP) were recovered using the Inject Star machine and samples BP and PP using the Poss deboner. Meat temperatures were measured immediately after the mechanical separation.

\begin{tabular}{llc}
\hline Samples & Origin of bones & $\begin{array}{r}\text { Temperature } \\
\text { of MDM }\left({ }^{\circ} \mathrm{C}\right)\end{array}$ \\
\hline BI1 & Beef, bones of bulls & 10.2 \\
BI2 & Beef, backbones of bulls & 10.3 \\
BI3 & Beef, bones of cows & 13.0 \\
BP & Beef, bones of cows & 17.0 \\
PI1 & Pork, bones of pigs & 10.3 \\
PI2 & Pork, bones of pigs & 8.8 \\
PI3 & Pork, aged bones of pigs & 9.7 \\
PP & Pork, bones of pigs & 15.0 \\
\hline
\end{tabular}


japortti in Mikkeli and partly in Hämeenlinna at the Finnish Meat Research Centre. The machine mainly used in the tests was a pressure type Inject Star (P-60) machine (Hollstein-Fuhrman, Vienna, Austria). The other machine was an auger-type Poss (PDX) machine (Poss Limited, Hamilton, Canada) from the production plant of Lihapolar in Kuopio.

\section{Packaging and storage properties}

Immediately after the mechanical deboning, the test meats for freezing were packaged in $3 \mathrm{~kg}$ samples in high density polyethylene (HDPE)-coated cartons and frozen. Samples for $+4^{\circ} \mathrm{C}$ storage tests were packaged in HDPE plastic bags.

Storage properties were studied at $+4^{\circ} \mathrm{C}$ after (0), $1,(2), 3,(5), 6$ days and at $-24^{\circ} \mathrm{C}$ after $1,63,84,112$ and 140 days.

\section{Analytical methods \\ Chemical analyses}

Moisture and fat. Moisture and fat were determined by the method of NiLSSON and KoLAR (12).

\section{Ash}

Ash contents were determined according to the Method K 27/1967 of the Finnish Meat Research Centre (13). The sample (10 g) was weighed into a porcelain crucible and dried at $135^{\circ} \mathrm{C}$ for one hour. The sample was ashed and weighed after cooling in a desiccator for $1 / 2 \mathrm{~h}$.

\section{Calcium and bone particles}

To determine the amount of calcium, complexometric EDTA-titration was used (14). The size of the bone particles was determined by the KOH-method (15). A homogenized sample was dried and boiled in an alcoholic $\mathrm{KOH}$ solution and dried. The bone particle content was calculated from the dry weight. The average size of the bone particles was determined by microscopy.

\section{Phosphate}

Phosphate content was analysed as ammonium phosphomolybdate with a TechniconAnalyzer II, technicon industrial method No 328-74A, 1975.

\section{Protein}

Protein contents were analysed according to the AOAC method (16). The amino acid analyses were carried out using the Waters associates chromatography-systems according to Dong and GANT (17) and Hsu et al., (18) at the Food Research Laboratory of the Technical Research Centre of Finland.

\section{Peroxide value and free fatty acids}

Peroxide oxygen content (milliequivalents of oxygen $/ \mathrm{kg}$ ) was determined iodometrically by adding potassium iodide into an acidified solution. The liberated free iodine was titrated with thiosulpahte. The percentage of free fatty acids (FFA-\%) was obtained by titrating with alkali (Methods K 31/1.12.1967 and K 32/1.12.1967 of the Finnish Meat Research Centre which are modified by according to WHEELER 19).

\section{Thiobarbituric acid value (TBA value)}

The TBA value denotes mg of malonaldehydes in $1000 \mathrm{~g}$ of fat (20).

\section{Connective tissue}

Connective tissue was estimated from the content of hydroxyproline, a characteristic component of collagen (21). The method is based on oxidization of hydroxyproline and subsequent hydrolysis to pyrrole with kloramin, which results in the formation of red coloured dimethylaminobenzoaldehyde. The absorption was measured at $560 \mathrm{~nm}$ (22).

\section{pH value}

$\mathrm{pH}$ was determined with $\mathrm{pH}$-meter WTW 521 (Wissenschaftliche-Technische Werkstätten, GMBH) with Ingold-electrode, 405-60-5S. 


\section{Microbiological methods}

\section{Aerobic plate count}

The total count of aerobic microorganisms was cultivated on Plate Count agar (Tryptoneglucose-yeast agar, Difco) at $30^{\circ} \mathrm{C}(72 \mathrm{~h})$, according to the Method 86/1986 of the Nordic Committee on Food Analysis.

\section{Coliform bacteria}

For evaluation of coliform bacteria the Method 44/1975 of the Nordic Committee on Food Analysis was used (24). The coliforms were evaluated both at $37^{\circ} \mathrm{C}(24 \mathrm{~h})$ and at $44^{\circ} \mathrm{C}(24 \mathrm{~h})$ using VRB-agar (Difco).

\section{Faecal streptococci}

Faecal streptococci were determined by the Method 68/1978 of the Nordic Committee on Food Analysis using M-Enterococcus Agar (Difco) at $37^{\circ} \mathrm{C}(48 \mathrm{~h})$.

\section{Lactic acid bacteria}

Lactic acid bacteria were quantified using the standard microbiological instructions, and were cultivated in Rogosa Agar (LBS-agar, BBL) at $+37^{\circ} \mathrm{C}(72 \mathrm{~h})$.

\section{Physical methods \\ Colour}

The colour intensities of the samples were determined using a reflectometer (Diffusion Systems LTGD, (Hanwell, London, UK, model 43). Diffuse reflection by scattering, in contrast to regular reflection, allows penetration of light into the material and the absorption of this energy during the reflection process (23). The device records the colour as a meter reading on a percent scale and was calibrated to a white $100 \%$ reading and a given grey $36 \%$ reading.

\section{Statistical analysis}

The results were analysed statistically using a Multiplan graph method and the WindowsExel graph programme. Standard deviations were calculated for all the variables studied during storage. Two-tailed t-tests were used to evaluate differences between the samples. Analyses were carried out on three samples in duplicate.

\section{Results and Discussion}

Basic composition. In plotting the basic composition of the samples, the following parameters were analysed; fat, dry matter, protein, ash, calcium, phosphate, connective tissue protein, colour and $\mathrm{pH}$.

Fat content. The objective of this study was to obtain samples in which the fat contents varied as much as possible. In beef samples, sample BI3 had the highest fat content, 29.8\% and sample BP the lowest, 23.6\% ( $\mathrm{P}<0.005)$. In the pork samples, sample PP had the highest fat content, $20.7 \%$ and sample PI1 the lowest, $18.2 \%(\mathrm{P}<0.05)$ of the values analysed (Table 2.)

The content of dry matter varied in accordance with the fat content, ranging between 35.4 and $44.4 \%$.

Protein content. In beef samples, sample BP had a slightly higher protein content than the other samples, especially compared with sample BI1. In pork samples, no significant differences were found with the exeption of samples PI2 and PP (Table 2). The amino acids were determined and the essential amino acid (EAA) profile (lysine, methionine, cystine, threonine, isoleucine, leucine, valine, phenylalanine and tyrosine and aiso tryptophane) of the samples was calculated according to the method of Hsu et al. (18). In this method, proteins are hydrolysed in $6 \mathrm{~N} \mathrm{HCl}$ solution and analysed using an amino acid analyser. The results are presented in Table 3. Sample PI1 had the highest analysed values of the following amino acids: phenylalanine, histidine, arginine and cystine. FIELD (24) also reported that because bone marrow, as well as blood, contains liberal amounts of lysine, leucine and histidine, these amino acids 
Table 2. Composition of mechanically deboned meat.

\begin{tabular}{|c|c|c|c|c|c|c|}
\hline Sample & Fat $\%$ & Protein \% & Ash $\%$ & Calcium\% & Phosphate \% & СТ \% \\
\hline \multicolumn{7}{|l|}{ MDB } \\
\hline BI1 & $26.2^{\mathrm{ab}}$ & $13.85^{\mathrm{a}}$ & $1.39 \mathrm{~d}$ & $0.29 \mathrm{~d}$ & $0.54^{d}$ & $1.49^{e}$ \\
\hline BI2 & 27.78 & 14.45 & $1.30^{e}$ & $0.26^{e}$ & $0.53^{e}$ & $1.68^{\mathrm{d}}$ \\
\hline BI3 & $29.8^{\text {bd }}$ & 14.00 & $1.30^{f}$ & $0.27^{f}$ & $0.55^{f}$ & $1.45^{f}$ \\
\hline BP & $23.6^{\text {agd }}$ & $15.85^{\mathrm{a}}$ & $2.94^{\text {def }}$ & $0.86^{\text {def }}$ & $1.16^{\text {def }}$ & $2.89 \mathrm{def}$ \\
\hline \multicolumn{7}{|l|}{ MDP } \\
\hline PI1 & $18.2^{\mathrm{ab}}$ & 15.40 & $1.13^{8}$ & $0.18^{8}$ & 0.478 & $1.14^{e}$ \\
\hline PI2 & 19.5 & $15.35^{a}$ & $1.20^{\mathrm{h}}$ & $0.19^{\mathrm{h}}$ & $0.46^{\mathrm{h}}$ & $1.04^{d}$ \\
\hline PI3 & $20.3^{a}$ & 15.75 & 1.09 & $0.12^{i}$ & $0.45^{i}$ & $1.41^{f}$ \\
\hline PP & $20.7^{b}$ & $16.05^{\mathrm{a}}$ & 3.14 ghi & $0.94^{\text {hhi }}$ & $1.26^{\text {ghi }}$ & $1.91^{\text {def }}$ \\
\hline
\end{tabular}

BI1, BI2 and BI3 are MDB and PI1, PI2 and PI3 MDP from Inject Star deboner. BP and PP are MDB and MDP from Poss deboner. CT \% is connective tissue. Mean values in the same column (in the groups of MDB and in the groups of MDP) bearing a common superscript are significantly different, ab $\mathrm{P}<0.05$, def $\mathrm{P}<0.005$ and ghi $\mathrm{P}<0.001$.

Table 3. Amino acid composition of proteins in mechanically deboned meat. Amino acid content, $\mathrm{g} / 16 \mathrm{~g}$ nitrogen.

\begin{tabular}{|c|c|c|c|c|c|c|c|}
\hline Amino acid & BI1 & BI2 & BI3 & BP & PI1 & PI2 & PP \\
\hline Aspartic acid & 10.3 & 10.3 & 9.7 & 10.0 & 11.7 & 8.7 & 9.9 \\
\hline Threonine & 4.5 & 4.7 & 4.4 & 4.4 & 4.7 & 3.5 & 4.6 \\
\hline Serine & 6.9 & 6.6 & 6.2 & 3.7 & 7.0 & 3.2 & 7.0 \\
\hline Glutamic acid & 13.6 & 15.4 & 13.5 & 15.4 & 16.5 & 12.7 & 14.2 \\
\hline Proline & 5.0 & 5.9 & 5.3 & 5.9 & 4.1 & 3.9 & 6.3 \\
\hline Glysine & 7.2 & 6.5 & 6.6 & 8.4 & 5.8 & 4.6 & 7.3 \\
\hline Alanine & 7.0 & 6.8 & 6.5 & 6.8 & 6.6 & 5.4 & 6.6 \\
\hline Valine & 5.1 & 5.0 & 4.8 & 4.2 & 5.1 & 4.5 & 4.6 \\
\hline Methionine & 2.0 & 2.1 & 2.1 & 1.9 & 2.0 & 1.7 & 2.2 \\
\hline Isoleucine & 4.0 & 4.3 & 4.1 & 3.5 & 4.7 & 3.7 & 4.2 \\
\hline Leucine & 8.1 & 8.5 & 8.3 & 7.2 & 8.5 & 7.9 & 7.4 \\
\hline Tyrosine & 3.1 & 3.2 & 3.2 & 3.0 & 3.9 & 3.0 & 3.3 \\
\hline Phenylalanine & 4.5 & 4.5 & 4.3 & 3.7 & 6.3 & 5.2 & 4.1 \\
\hline Lysine & 8.5 & 8.0 & 7.6 & 6.5 & 8.1 & 9.3 & 7.6 \\
\hline Histidine & 4.3 & 4.3 & 4.0 & 3.5 & 4.7 & 3.6 & 4.1 \\
\hline Arginine & 6.9 & 6.4 & 6.0 & 6.4 & 7.2 & 5.5 & 7.0 \\
\hline Cystine & 1.4 & 1.0 & 1.0 & 0.8 & 1.5 & 1.0 & 0.7 \\
\hline EAA & $89 \%$ & $86 \%$ & $87 \%$ & $81 \%$ & $89 \%$ & $81 \%$ & $83 \%$ \\
\hline
\end{tabular}

BI1, BI2, BI3 are mechanically deboned beef samples from the Inject Star deboner. BP is from the Poss deboner. PI1, PI2 and PP were corresponding samples of mechanically deboned pork. EAA is essential amino acid profile.

are proportionally more abundant than others in mechanically deboned meat.

The protein contents, calculated from the amounts of nitrogen, were higher in samples recovered in the Poss machine than in samples recovered in the Inject Star machine. The protein content of PP was $16,05 \%$ and that of BP was $15,85 \%$. However, the EAA values of these samples were low: the value of the BP sample was the lowest at $81 \%$ and that of the PP was the third lowest at $83 \%$. This was probably caused by a higher proportion of protein originating from connective tissue. Beef and pork samples recovered in the Poss machine had the highest connective tissue protein contents. In all samples these contents varied from $1.04 \%$ to $2.89 \%(\mathrm{P}<0.05)$ (Table 2).

Contents of ash, calcium and phosphate. Ash, calcium and phosphate contents of the samples depended largely on the method of meat separation used. The samples recovered 


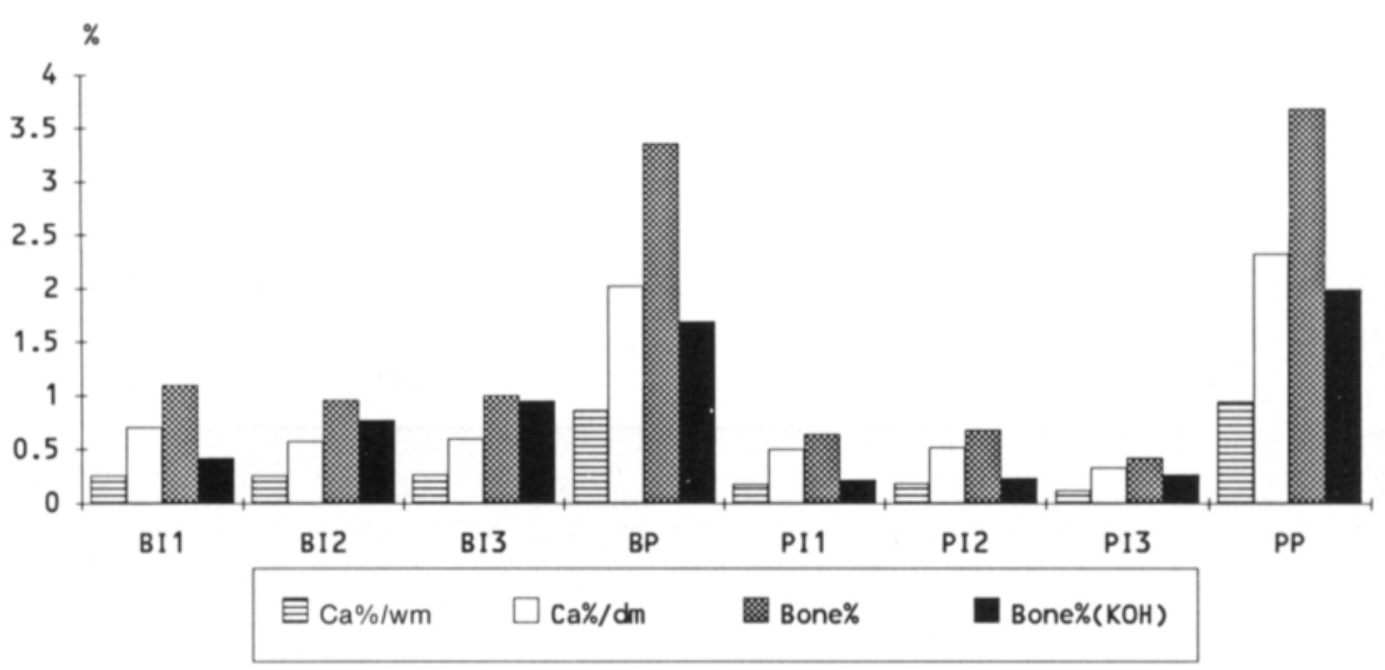

Fig. 1. The contents of calcium and bone particles in mechanically deboned meat. $\mathrm{Ca} /$ whole matter (wm), $\mathrm{Ca} / \mathrm{dry}$ matter (dm), Bone $\%$ /whole matter measured on basis of $\mathrm{Ca} \%$ content (Bone $\%$ ) and Bone $\%$ determined using the KOH-method (Bone\% (KOH)). The differences between samples BP, PP and samples BI1, BI2, BI3, PI1, PI2, PI3 were significantly different $(\mathrm{P}<0.005)$.

by Inject Star had the following ash contents: beef $1.30-1.39 \%$ and pork $1.09-1.20 \%$. The ash content of both beef and pork samples recovered in the Poss machine was about $3.00 \%$ ( $\mathrm{P}<0.001$, Table 2$)$. The calcium content, which is also of legislative interest, increased in Poss pork samples to $2.32 \%$ and in Poss beef samples to $2.02 \%$ of the dry matter content. The beef samples recovered using the pressure-based Inject Star machine had dry matter calcium contents ranging between $0.58 \%$ and $0.71 \%$, for pork samples the corresponding figures were $0.50-0.52 \%(\mathrm{P}<$ 0.001), (Fig.1).

Phosphate contents were also higher in samples recovered using the Poss machine, which is based on scraping, than in samples recovered using the Inject Star machine (Table 2).

The bone contents of the samples, evaluated by the $\mathrm{KOH}$-method, are presented in Figure 1. The bone contents of the Poss and Inject Star samples were significantly different $(\mathrm{P}<0.005)$. Of the bone fragments obtained in the analysis, the length and breadth of 100 bone particles were determined by microscopy. The results are presented in Figure 2.
On average the sample BP had the largest bone particles and sample PP the smallest particles.

When comparing calcium and ash contents of meat derived from different anatomical sites and species with the same machine, the sow loin bones and back bones of veal gave the lowest values, $0.41 \%$ and $0.54 \%$ respectively (25). Low-fat meat contains approximately $12 \mathrm{mg}$ of calcium in $100 \mathrm{~g}$, and its ash content is about $1.2 \%$, whereas the corresponding figures for fatty meat are $3 \mathrm{mg}$ and $0.2 \%$ respectively $(26,27,28)$. According to Newman (29) the presence of a certain amount of calcium in the form of powdered bone in mechanically deboned meat should be beneficial from the point of view of nutritional quality.

Colour. The colour intensity of the samples, which was measured by a diffusion method, ranged in beef samples between 20.0 and 25.0 and in pork samples between 16.3 and 25.3. Samples recovered in the Poss machine were more homogenous and lighter in colour, which can also be seen in the results presented in Figure 3. OCKERMAN (30) reported that 


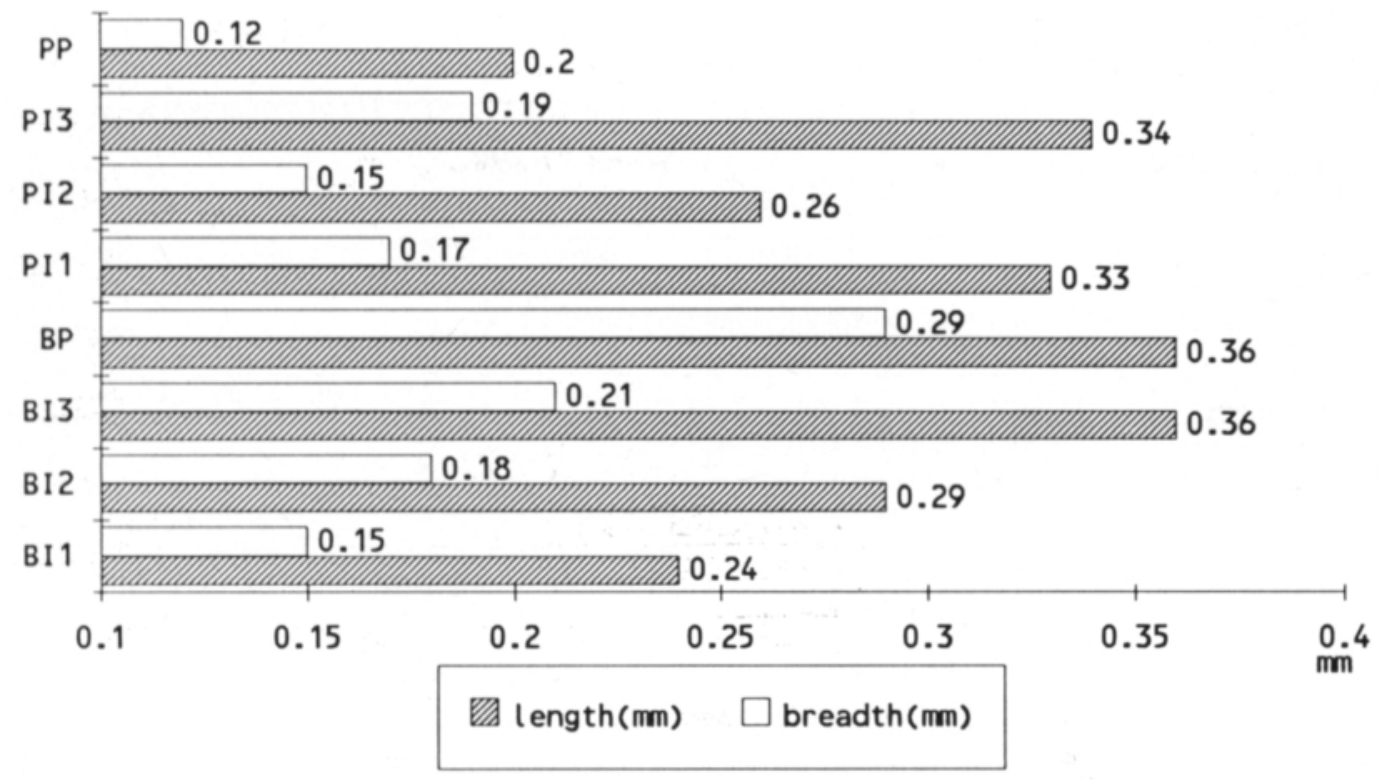

Fig. 2. The size of bone particles in test samples. One hundred particles were measuerd from each sample. Standard deviations within each sample were $0.09-0.85$. BI1, BI2, BI3 are mechanically deboned beef samples from the Inject Star deboner. BP is from the Poss deboner. PI1, PI2, PI3 and PP are corresponding samples of mechanically deboned pork.

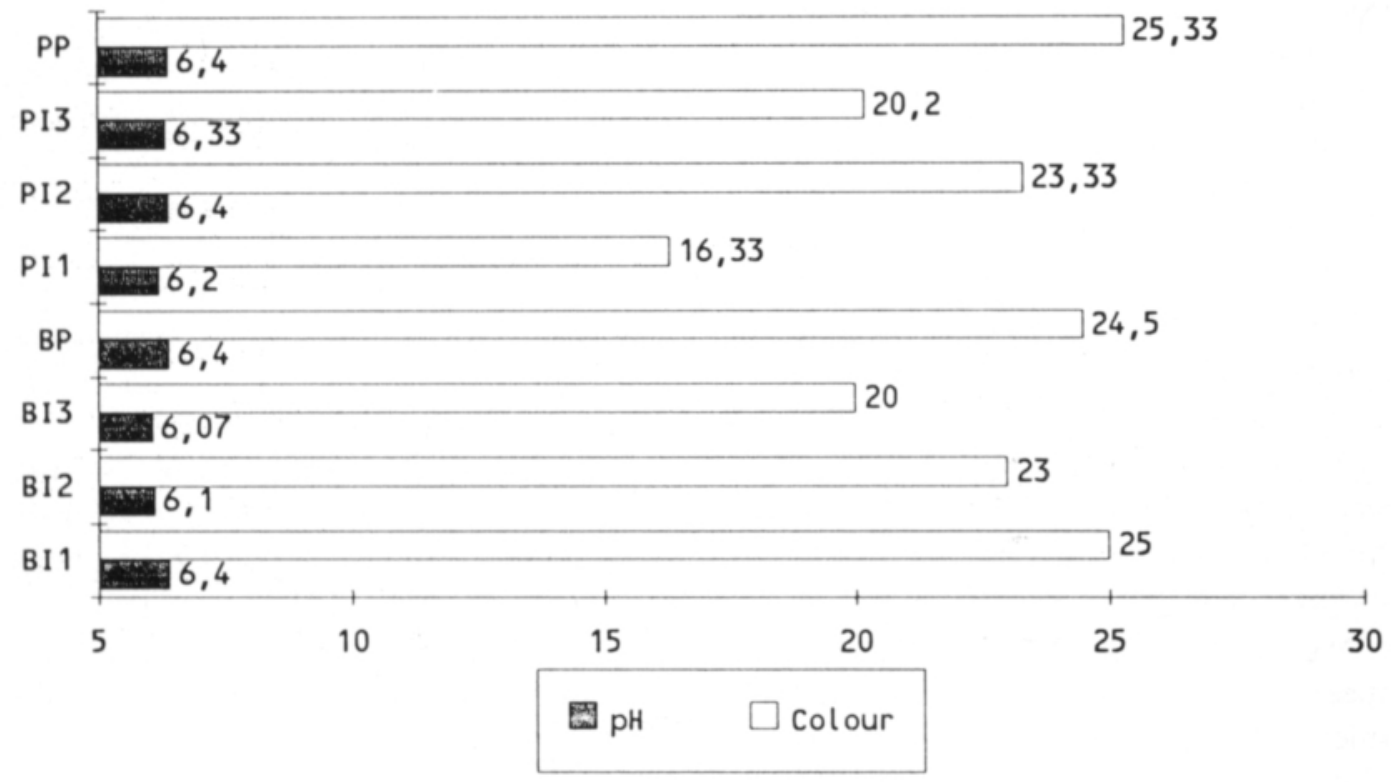

Fig. 3. Comparison of $\mathrm{pH}$ and colour $(\%)$ in fresh samples of mechanically deboned beef and pork. Standard deviations were $\leq 0.07$ in the $\mathrm{pH}$ values and $0.2-1.2$ in the colour values. BI1, BI2, BI3 are mechanically deboned beef samples from the Inject Star deboner. BP is from the Poss deboner. PI1, PI2, PI3 and PP are corresponding samples of mechanically deboned pork. 


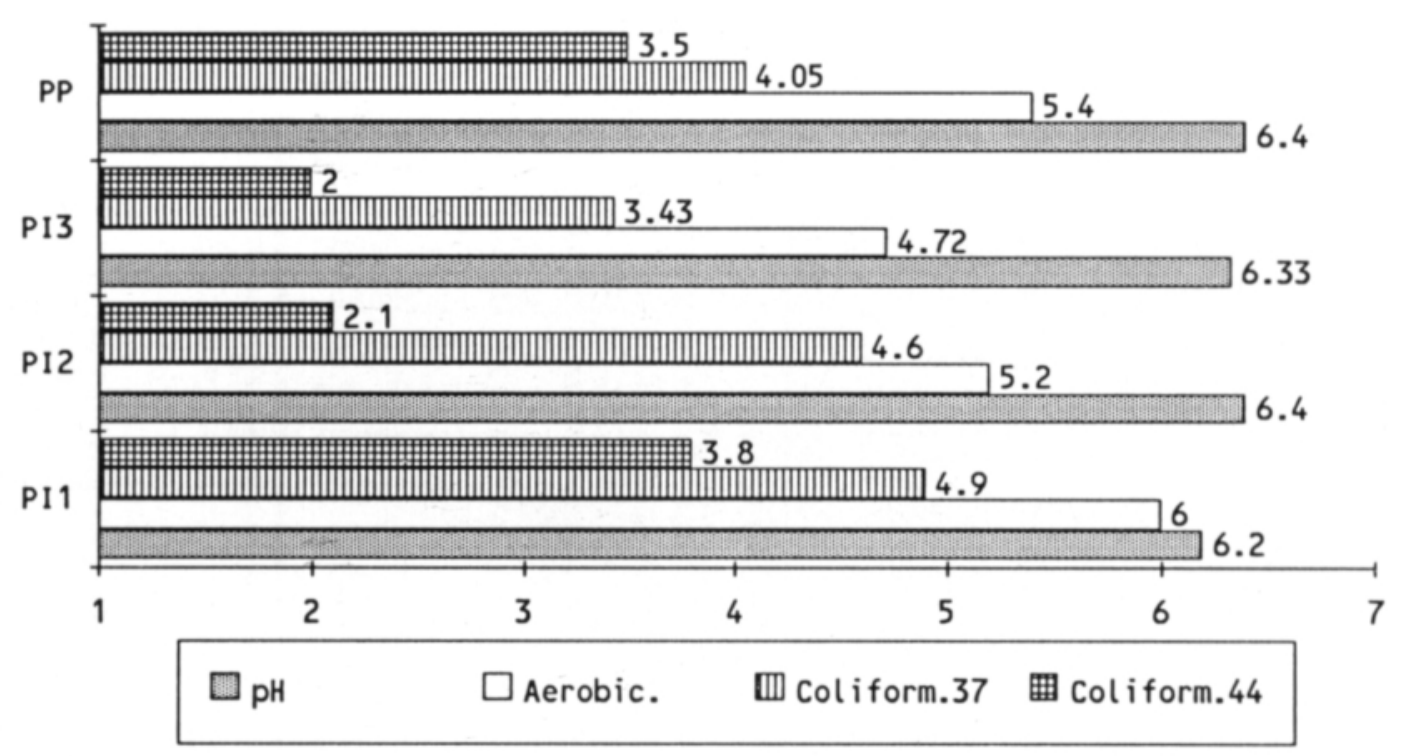

Fig. 4. Comparison of microbial counts, $\log (\mathrm{cfu} / \mathrm{g})$, and $\mathrm{pH}$ in the fresh mechanically deboned pork samples. Standard deviations in $\mathrm{pH}$ values were $\leq 0.05$. PI1, PI2, PI3 are mechanically deboned pork samples from the Inject Star deboner, PP from the Poss deboner.

mechanically deboned tissue significantly darkened the colour of the raw material and also of the finished product. Due to myoglobin variation there are also colour variations between the meats of different species. The myoglobin content of pork is only about $25 \%$ of that of beef.

pH value. Immediately following slaughter, the $\mathrm{pH}$ of muscle is near neutral, i.e. 7.207.30. However the $\mathrm{pH}$ value starts to fall immediately, and after only one hour the $\mathrm{pH}$ of the muscle is about 6.2 and after 24 hours about 5.6. This is caused by the accumulation of lactic acid in the muscle (21).

In this work the $\mathrm{pH}$ ranges in all samples were $6.07-6.40$. No real differences were found between the samples recovered by the different machine types.

Microbial counts. Mechanically deboned meat is a very favourable growth medium for microbes, due to its rather high $\mathrm{pH}(4,24)$.

On the basis of the different analyses, samples BI2, PI3 (aged bones) and BP had the lowest microbe contents (Fig. 4). The shelf lives of BI2 and BP were very similar.

\section{Shelf life at $+4^{\circ} \mathrm{C}$}

Keeping qualities at $+4^{\circ} \mathrm{C}$ were investigated by analysing the samples after (0), 1, (2), 3, (5) and 6 days of storage. Classification was determined by different analysis methods.

pH value. Beef samples. The $\mathrm{pH}$ of sample BI1 did not change essentially during 5 days, although starting $\mathrm{pH}$ was rather high. $\mathrm{pH}$ of samples BI2 and BI3 was approximately 6.10 and increased slightly during the first two days. The rather high starting $\mathrm{pH}$ value of sample BP 6.40 decreased considerably during the first two days and at the end of the storage period it was 6.20.

Pork samples. The $\mathrm{pH}$ of sample PI1 remained constant for the first two days, then increased slightly during the subsequent three days of storage. Sample PI2 was similar to sample BP, whereas in sample PP, recovered using the Poss machine, the $\mathrm{pH}$ increased after two days from 6.40 to 6.50 and then fell sharply to 6.30 during the subsequent three days.

Changes in the quality of lipids. Beef samples. The free fatty acid value of sample BI2 


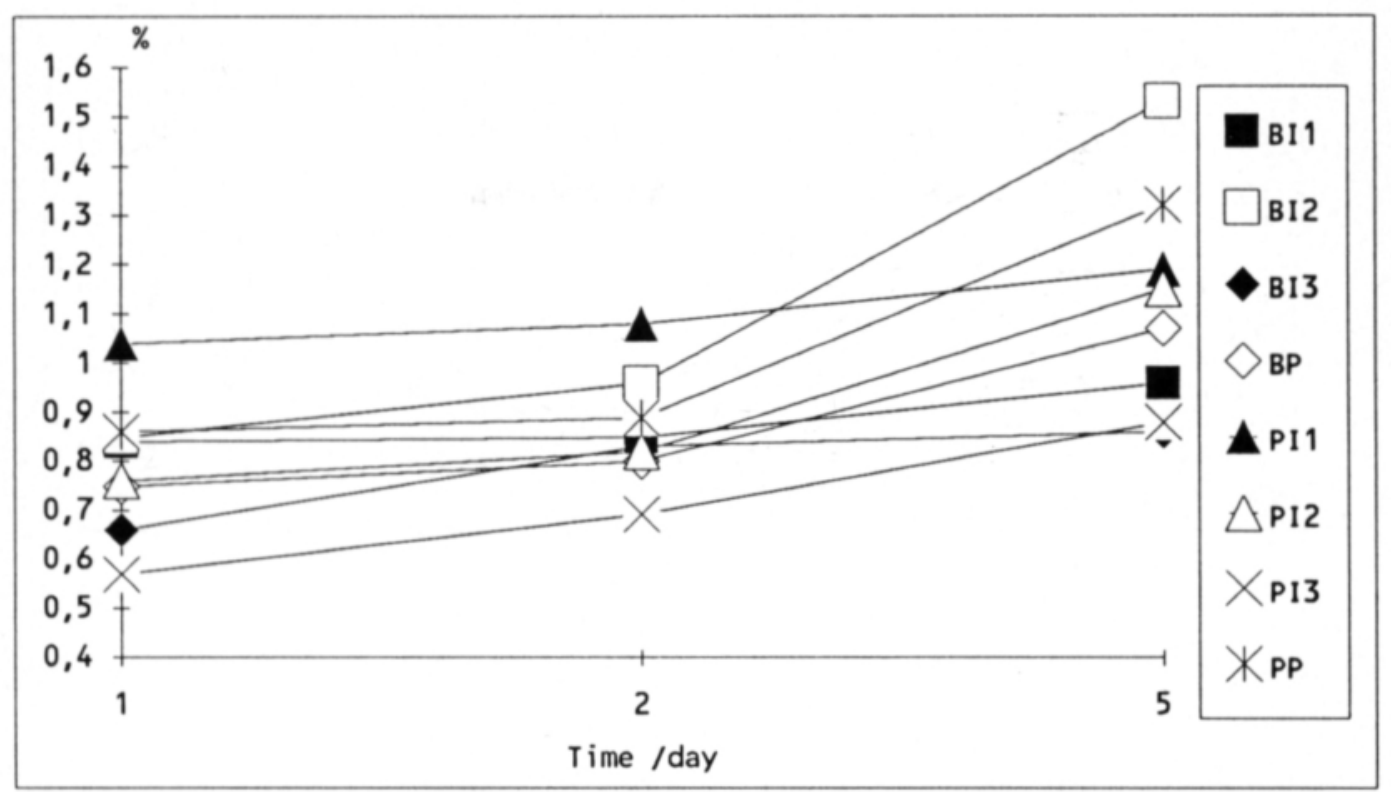

Fig. 5. Free fatty acid values (FFA \%) of mechanically deboned meat samples during storage at $+4^{\circ} \mathrm{C}$. Standard deviations were $<0.07$. BI1, BI2, BI3 are mechanically deboned beef samples from the Inject Star deboner. BP is from the Poss deboner. PI1, PI2, PI3 and PP are corresponding samples of mechanically deboned pork.

increased more than in the other samples, which all increased in a similar way after two days of storage (Fig. 5). Pork samples. Based on the starting figures and the follow-up in $+4^{\circ} \mathrm{C}$ storage, sample PI1 retained its quality the best. In examining the lipid quality by different analyses the quality of fat in meat is; when TBA value $<0.4 \mathrm{mg} / \mathrm{kg}$ the sample is good and if TBA value $>1.1 \mathrm{mg} / \mathrm{kg}$ the sample is poor. On the other hand if peroxide value $<2 \mathrm{meqO} / \mathrm{kg}$ the sample is good and when FFA- $\%$ value $<1$ the sample is good (31).

Microbiological changes. According to KÄRKKÄINEN (11) the surface and inside flora of meat kept in cold storage is composed mainly of gram-negative bacteria, belonging to the genera Pseudomonas, Alcaligenes, Achromobacter, Flavobacterium and Serratia and gram-positive Micrococcus. After slaughtering, depending on slaughter hygiene, the bacterial count on the surface of the carcass is $10^{2}-10^{4} \mathrm{cfu} / \mathrm{cm}^{2}$. In the case of pork this bacterial flora consists mainly of bacteria be- longing to the genera Pseudomonas and Lactobacillus.

Beef samples. The quantity and accumulation of bacteria in samples BI1 and BI2 were similar during the whole follow-up of the keeping qualities in storage. Compared with the other samples, the amount of aerobic bacteria in sample BI3 increased considerably more quickly (Fig. 6). Sample BP, recovered in the Poss machine, had a lower initial microbial content than the samples recovered by Inject Star. The count of all groups of microbes in sample BP showed the most obvious increase after two days. The lactobacillus count in sample BP was lower than in the other samples during the whole storage period, although the growth of the population was faster. The rapid growth of lactobacillus was also indicated by the reduction in $\mathrm{pH}$.

The count of thermotolerant coliform bacteria of sample BI1 remained lower than the corresponding microbial counts of the other samples throughout the storage period. Because these coliform organisms have the 


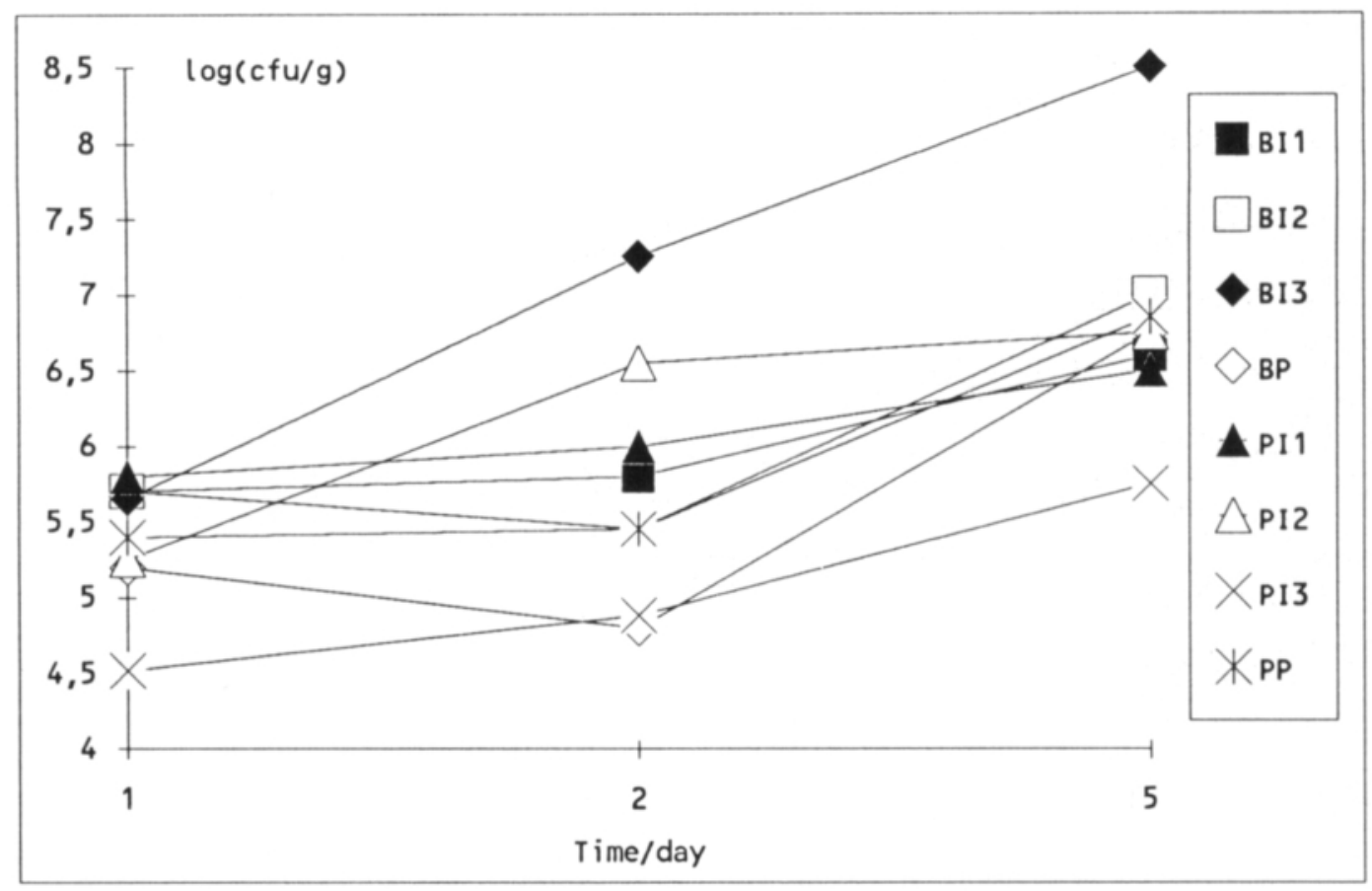

Fig. 6. Aerobic microbial counts of mechanically deboned meat samples during storage at $+4^{\circ} \mathrm{C}$. Standard deviations varied between 0.01 and 0.15 . BI1, BI2, BI3 are mechanically deboned beef samples from the Inject Star deboner. BP is from the Poss deboner. PI1, PI2, PI3 and PP are corresponding samples of mechanically deboned pork.

characteristics of faecal spoilage organisms, the original contamination of sample BI1 was less than in the other samples. Taking into account the keeping qualities of lipids and the microbiological keeping qualities, sample BI1 was the best, followed by samples BP, BI 2 and BI3.

Pork samples. The growth of the microbial genera analysed in samples PI1 and PI2 was very similar, apart from the count of lactic acid bacteria of sample PI1, which remained almost constant throughout the storage period.

The temperatures of the meats recovered from the Poss deboner were $13.0-15.0^{\circ} \mathrm{C}$ and from the Inject Star deboner $8.8-13.0^{\circ} \mathrm{C}$. It seems apparent that because the meat was for such a short time at the recovering temperature (before deboning the temperature was between $+4^{\circ} \mathrm{C}$ and $+6^{\circ} \mathrm{C}$, and immediately after deboning was reduced to $+4^{\circ} \mathrm{C}$ or $-40^{\circ} \mathrm{C}$ ), this temperature should not have a significant effect on the quality of mechani- cally deboned meats. According to NewMAN (29) legislation usually specifies the temperature below which the bones must be stored (usually $+7^{\circ} \mathrm{C}$ or less) and the maximum time of storage ( $3-5$ days, longer if stored below $0^{\circ} \mathrm{C}$ )

The keeping qualities of samples PI3 and PP were somewhat better than those of the other samples.

\section{Keeping qualities at $-24^{\circ} \mathrm{C}$.}

Keeping qualities in frozen storage were observed by analysing the samples after 1, 63, 84,112 and 140 days of storage. Some samples were also analysed after 28 days.

pH-value. Beef samples. Samples BI1 and $\mathrm{BP}$ had almost the same initial $\mathrm{pH}$ values, after which sample BP remained at a significantly higher level throughout the survey programme. Samples BI2 and BI3 were similar and had the lowest $\mathrm{pH}$ values at all the samplings. 


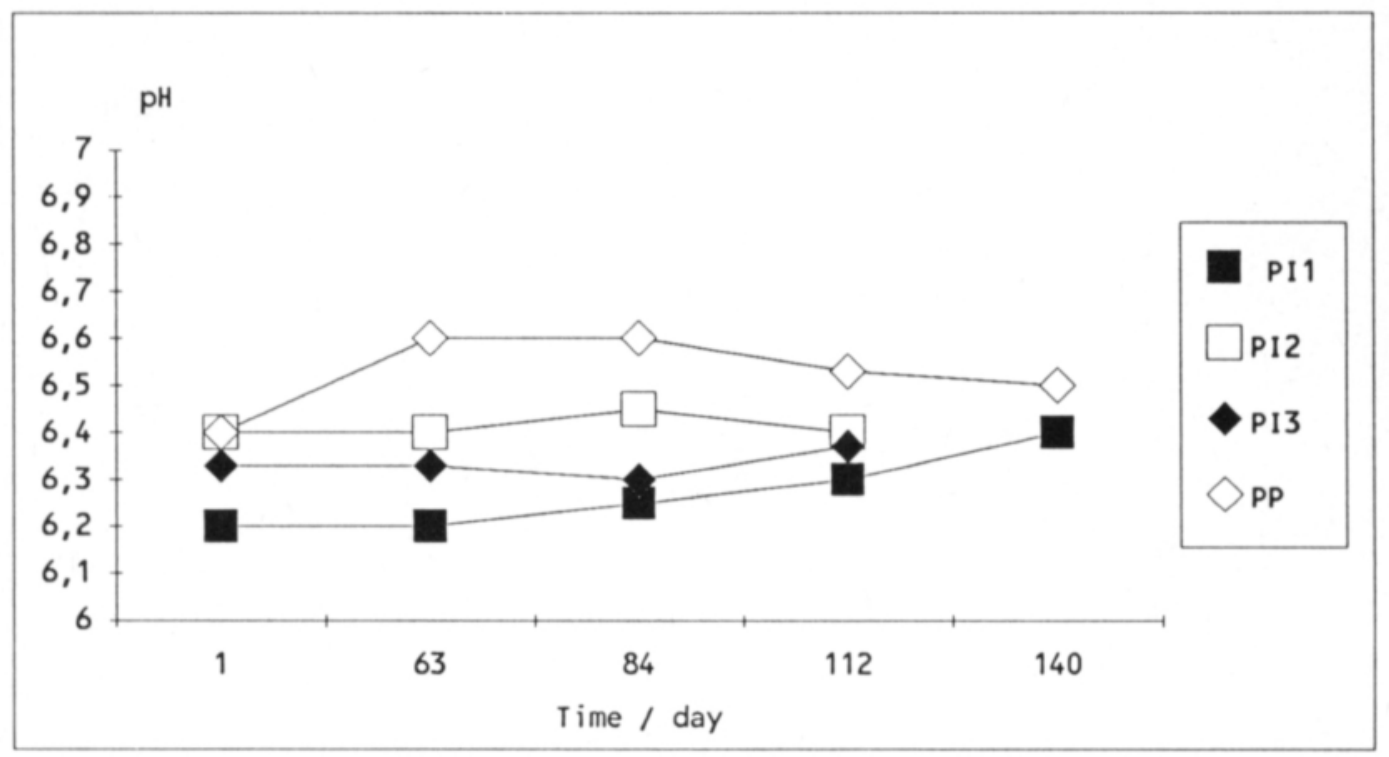

Fig. 7. The $\mathrm{pH}$ values of mechanically deboned pork samples during storage at $-24^{\circ} \mathrm{C}$. Standard deviations were $\leq 0.06$. PI1, PI2, PI3 are mechanically deboned pork samples from the Inject Star deboner, PP from the Poss deboner.

Pork samples. The changes of the $\mathrm{pH}$ values in pork samples were very similar to those in beef samples. In comparing the changes from the initial $\mathrm{pH}$ value in the meat recovered by the two machine types, $\mathrm{pH}$ in meat recovered using the Poss machine increased considerably higher, and remained higher throughout the whole survey programme, whereas the $\mathrm{pH}$ values of samples PI2 and PI3 remained constant (Fig. 7).

Colour. Beef and pork samples recovered using the Poss machine were lighter in colour than samples from the Inject Star. Otherwise, changes in all samples, except BI3, showed a similar random variation during frozen storage. The colour of sample BI3 remained almost constant.

Changes in lipid quality. Beef samples. The peroxide value of sample BI2 showed the greatest increase during the first 84 days, after which it almost levelled with BI1 (Fig. 8). The initial peroxide value of the BP sample was high, but it soon decreased and then remained below average.

The quantities of free fatty acids showed rather similar changes in all the samples, as did many other parameters of these samples.
Pork samples. All the pork samples behaved in a similar way. Rancidity advanced faster and more vigorously than in the beef samples.

On the basis of the TBA, peroxide and free fatty acid (FFA-\%) values, sample PI2 (mechanically deboned meat from bones of pigs recovered using the Inject Star deboner) was of inferior quality compared with the other samples. The sample recovered using the Poss machine scored between the samples recovered with the Inject Star.

The free fatty acids of the beef samples remained almost constant. The peroxide and TBA values of the pork samples indicated that pork fat deteriorates considerably faster than beef fat. This was particularly evident from the analysis results of the samples after 63 days of frozen storage. As expected, the free fatty acid values of pork samples were higher than those of beef, because pork fat contains more polysaturated fatty acids (Fig. 9).

\section{Microbial counts}

Beef samples. Samples BP and BI2 had the lowest aerobic plate count. The quantity of aerobic microbes in samples BI1 and BI3 remained almost constant throughout the period 


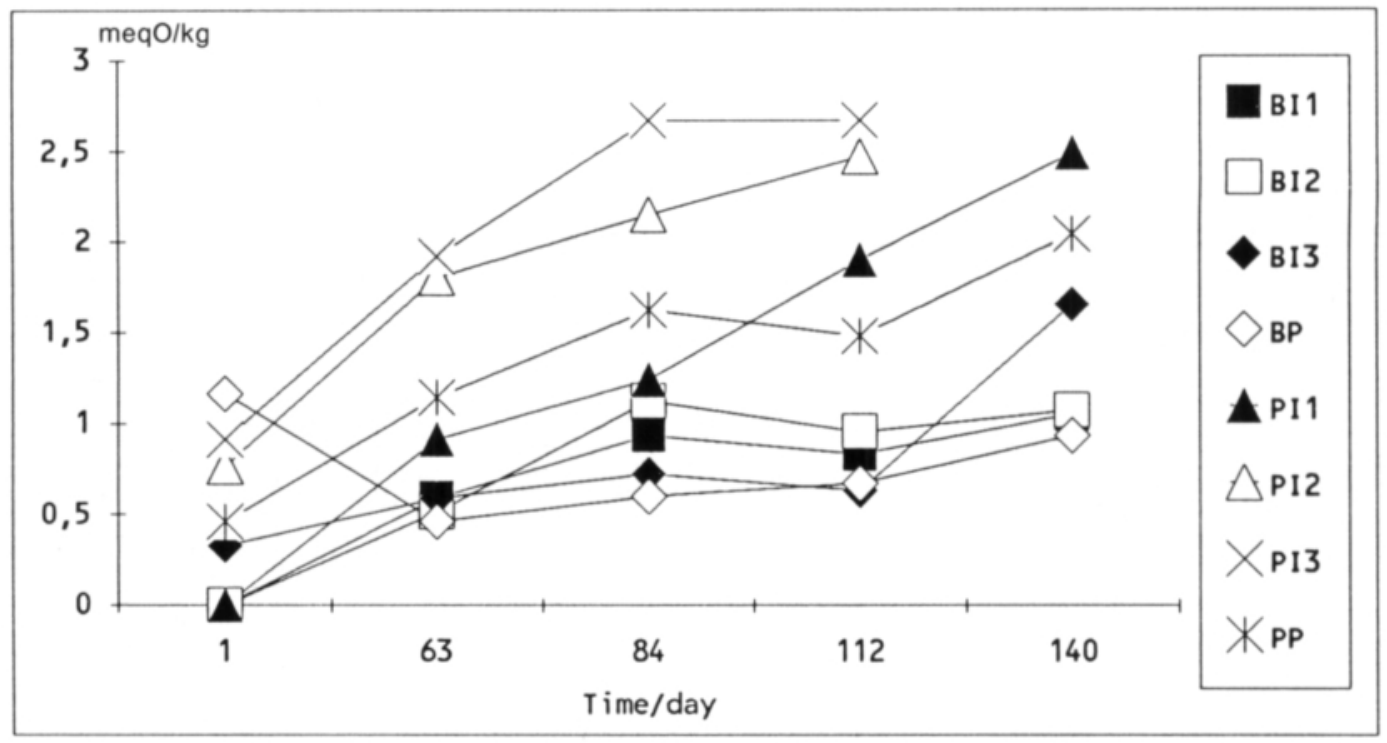

Fig. 8. Peroxide values (milliequivalents of oxygen $/ \mathrm{kg}$ ) of mechanically deboned meat samples during storage at $-24^{\circ} \mathrm{C}$. Standard deviations were $\leq 0.32$. BI1, BI2, BI3 are mechanically deboned beef samples from the Inject Star deboner. BP is from the Poss deboner. PI1, PI2, P13 and PP are corresponding samples of mechanically deboned pork.

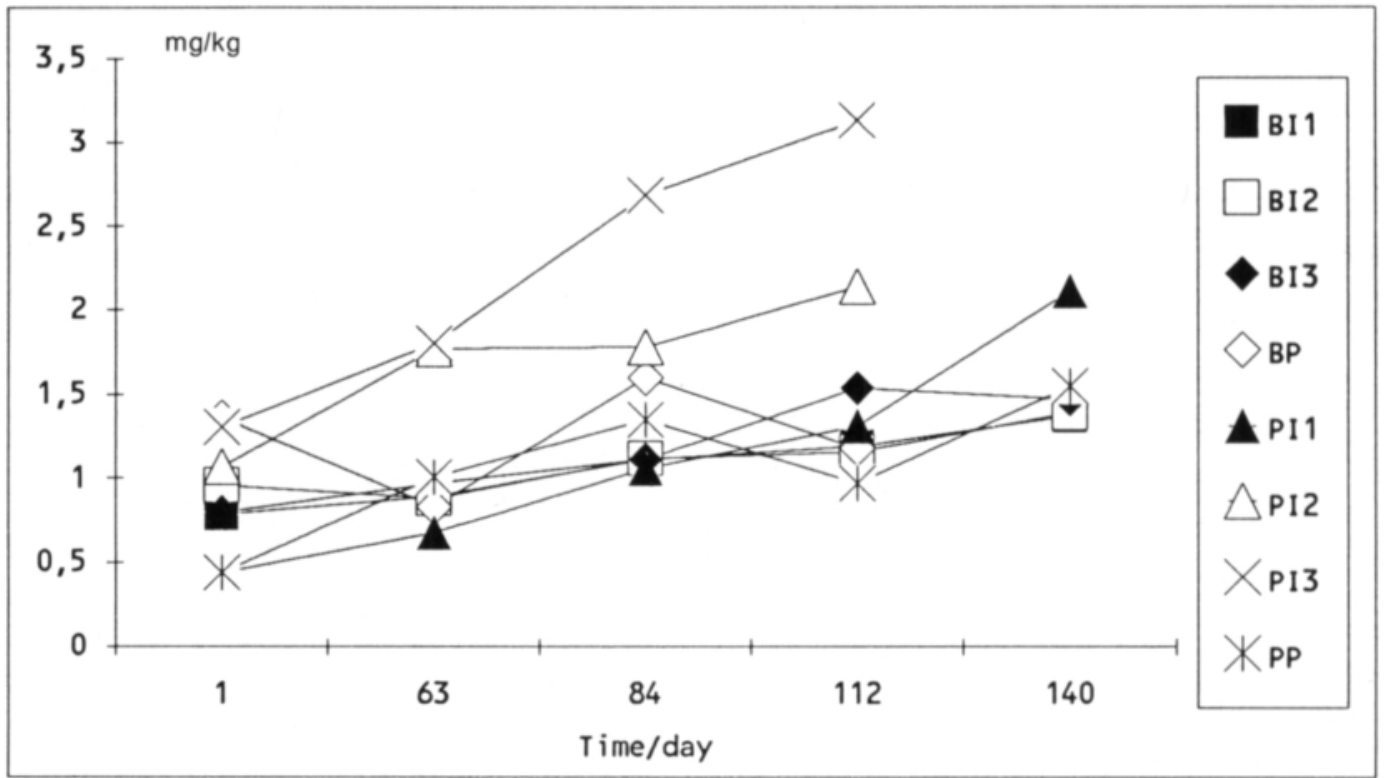

Fig. 9. Thiobarbituric acid values (TBA, $\mathrm{mg} / \mathrm{kg}$ ) of mechanically deboned meat samples during storage at $-24^{\circ} \mathrm{C}$. Standard deviations were $\leq 0.66$. BI1, BI2, BI3 are mechanically deboned beef samples from the Inject Star deboner. BP is from the Poss deboner. PI1, PI2, PI3 and PP are corresponding samples of mechanically deboned pork.

of frozen storage (Fig. 10). When studying coliform bacteria, sample BP was noted to have the lowest microbial counts during the survey.
The coliform count of sample BI3 increased clearly by the $63 \mathrm{rd}$ day, and then remained almost constant. Sample BP had the lowest counts of faecal streptococci and lactic acid 


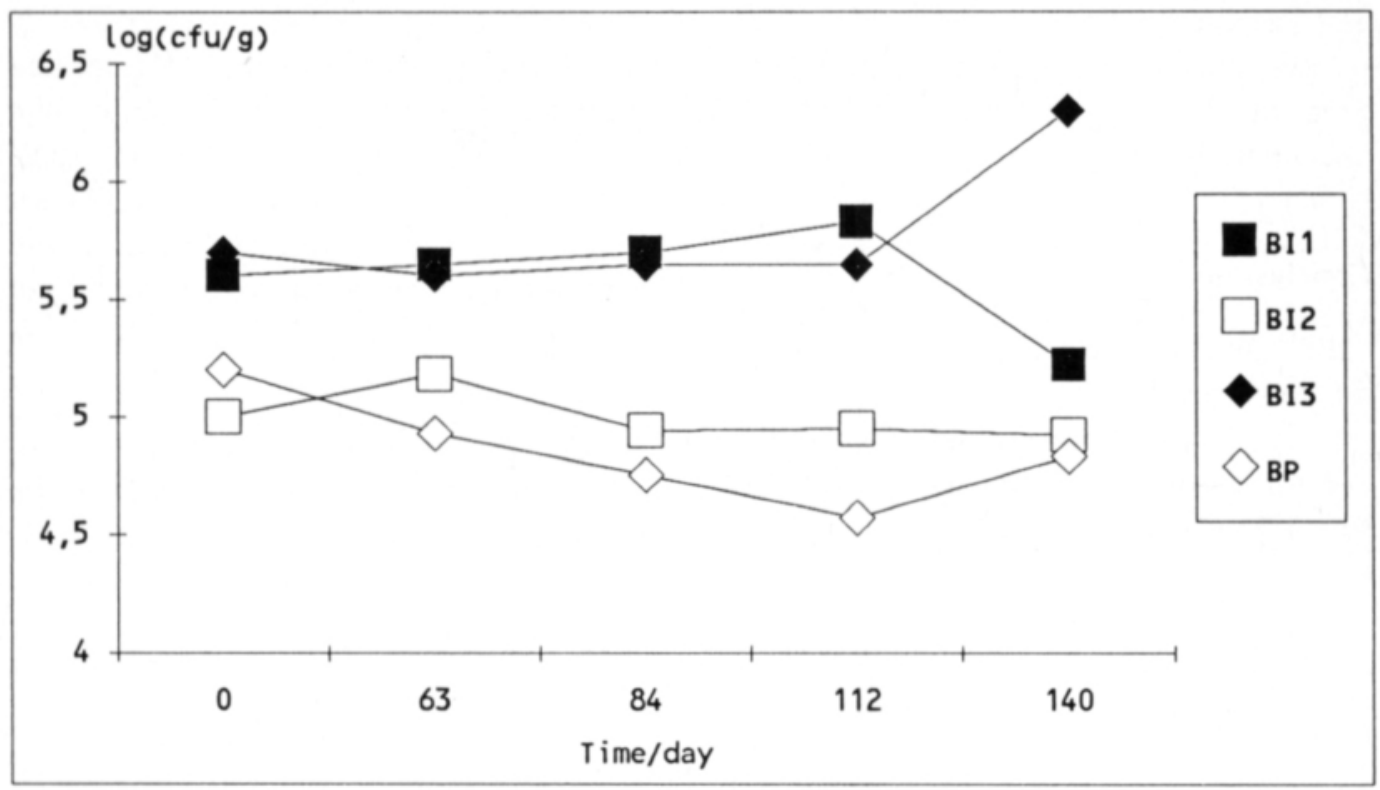

A.

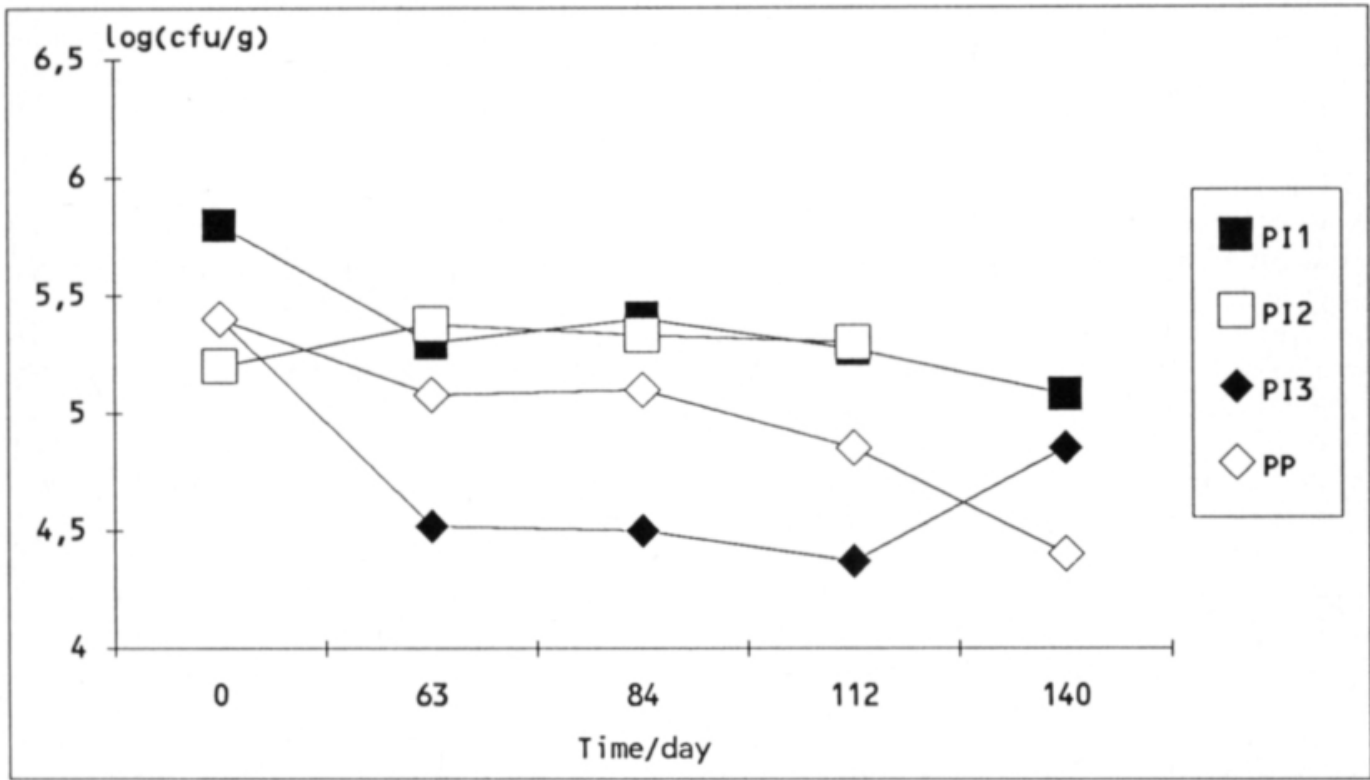

B.

Fig 10. Aerobic microbial counts, $\log (\mathrm{cfu} / \mathrm{g})$, during storage at $-24^{\circ} \mathrm{C}$ in $\left.\mathrm{A}\right)$ mechanically deboned beef samples and B) mechanically deboned pork samples. Standard deviations varied between 0.05 and 0.51 . BI1, BI2, BI3 are mechanically deboned beef samples from the Inject Star deboner. BP is from the Poss deboner. PI1, PI2, PI3 and PP are corresponding samples of mechanically deboned pork.

bacteria, and sample BI 2 the next lowest. The same applied to coliform bacteria, particularly in the case of coliform bacteria growing at $+44^{\circ} \mathrm{C}$. Sample BI1 had the third lowest of the above-mentioned bacterial counts.
Pork samples. Sample PI1 had higher counts of aerobic and faecal bacteria than sample PI2. In other respects it was similar to the other samples. On the basis of the coliform and faecal bacteria, sample PI2 had the 
best keeping qualities.

Frozen storage had very little effect on the count of lactic acid bacteria. All the samples had similar counts.

\section{Conclusions}

Both in cold and frozen storage, the beef samples generally maintained their quality better than the pork samples. The differences between the samples recovered using the pressure-based Inject Star deboner and the scrap- ing-based Poss-prototype deboner were clearly evident in the contents of ash, calcium and phosphate and dry matter. The microbial counts also differed. This investigation leads to the conclusion that, if MDB and MDP must be kept in cold or frozen storage, MDP should be used after shorter storage periods than MDB probably after no more than about six weeks.

Acknowledgements. We are grateful to Osuusteurastamo Karjaportti, Lihapolar Oy and Ulkomarkkinat Oy for financial support during this investigation.

\section{References}

1 Kastner, C.L. and Kropf, D.H., 1986. Processed meat products and safety issues. Dairy and Food Sanitation, 6: 186-193

2 von WINTER, F.F., 1978. Gewinnung und Verarbeitung von Separatorenfleisch. Die Fleischerei 29(7): 9-11

3 Goldstrand, R.E., 1975. Mechanically deboned meat yields and product characteristics. Proc. 28th Reciprocal Meat Conference, Chicago, 116

4 Field, R.A., Kruggel, W.G. and Riley, M.L., 1976. Characteristics of MDM hand separated meat and bone residue from bones destined for rendering. J. Anim. Sci. 43: 755-758

5 Field, R.A., Riley, M.L. and Corbridge, M.H., 1974. Influence of yield on calsium content of mechanically deboned lamb and mutton. J. Food Sci. 39: 285-287

6 Field, R.A., Olson-Womack, S.L. and Kruggel, W.G., 1977. Characterization of bone particles from mechanically deboned meat. J. Food Sci. 42: 1406-1407

7 Grunden, L.P. and Mac NeIL, J.H., 1973. Examination of bone content in mechanically deboned poultry meat by EDTA and atomic absorption spectrophotometric methods. J. Food Sci. 38: 712-715

8 Bijker, P.G.H., Gerats, G.E., Van Logtestijn, J.G., Koolmees, P.A. and Fransen, T., 1979. Methods to determine the bone content and size of the bone particles in mechanically deboned pork. Proc. 25 th Eur. Meet. Meat Res. Work., Budapest, pp. $845-849$

9 Field, R.A., 1976. Increased, Animal Protein Production with mechanical Deboners, World Review of Animal Production, Vol. XII, No.1 Jan-Mar pp. $61-73$

10 Roberts, T.A., 1987. Microbiology and Hygiene of
Red meats, 33th International Congress of Meat Science and Technology pp. 43-45

11 KärkKäıInen, T., 1987. Meat and Meat Products, Shelf-life and quality in cold storage, The Finnish Engineers' Post-Graduate Institute (in Finnish) 178-87 pp. $1-6$

12 Nilsson, R. and KolaR, K., 1971. The determination of fat content in meat and meat products by nuclear magnetic resonance. Proc. 17th Eur. Meet. Meat Res. Work., Bristol, pp. 299-303

13 Anonymous, 1967. Ash content. Method K 27/1.12.1967 of the Finnish Meat Research Centre (in Finnish).

14 Batton, J., Reder, W., 1956. New indicator for titration of calcium with (ethylen-dinitrilo)tetra-acetate. Anal. Chem. 28: 1026-1028

15 Bijker, P.G. and Koolmees, P.A., 1985. Bepaling van de harde- botresten grootte van de botdeeltjes in separatorvlees. Tijdschr. Dier geneeskd, 110: 969970

16 Anonymous, 1975. Determination of protein content by the Makro Kjeldahl method. AOAC 1975

17 Dong, M.W. and GANT, J.R., 1985. Highspeed liquidchromatographic analysis of amino acids by postcolumn sodium hypochloride-o-phtalaldehyde reaction. J.Chromatocraphy 327: 17-25

18 Hsu, G.W., Sutton, M.O., Banjo, M.O., Satterlee, L.D. and Kendrick, J.G., 1978. The C-PER and TPER asseys for protein quality, Food Technol. 32(12): $68-73$

19 Wheeler, D.H., 1961. Öle und Fette. DGFC-IV6A, 7

20 Sedlacek, B.A.J., 1958. Beurteilung der Walnusskerne durch objektiv Ranzigkeit- Methoden. z.L.U.F. 107: pp. 28-32

21 Price, J.F. and Schweigert, B.S., 1987. The Science of Meat and Meat Products. Westport, pp 81-88 
22 WeBer, R., The determination of hydroxyproline and chloride in meat and meat products. Simultaneus operation with nitrogen and phosphorus determinations. Nr 7 (1973) Technicon International Division SA, Geneve

23 Stark, E.W., 1986. Diffuse Reflection. Uses that affect our Lives, The Physics Teacher 3, 144-152

24 FIELD, R.A., 1975. Recovery of protein from bones by mechanical deboners. Proc. 21th Eur. Meet. Meat. Res. Work., Bern, pp. 100-101

25 Field, R.A., 1976. Mechanically deboned red meat. Food Technol. 30(9): 38-48

26 Field, R.A. and Arasu, P., 1981. A simple method for estimating amount of red marrow present in mechanically deboned meat. J. Food Sci. 46: $1622-1623$

27 Prost, E., 1984. Nutritive value of mechanically de- boned meat, Meat, Poultry and Game. Medycyna, Weterynaryjna; 40: pp.666-670; 0017 Ref;

28 FiELD, R.A., 1981. Current status of mechanically deboned beef and pork. Proceedings of 34th Ann. Reciprocal Meat Conference, Pub. National Livestock and Meat Board.Chicago, III pp.143-146

29 Newman, P.B., 1980. The separation of meat from bone - A review of the mechanics and problems. $\mathrm{M}$. Sci.5: $171-200$

30 Ockerman, H.W., Houben, J.H. and Krol, B., 1985. Effect of Bone Source and Storage on the Role of Mechanically Deboned pork in Rancidity Development in a Cooked and Smoked Sausage. J.Food Sci. 50: 1551-1555

31 Ронја, M.S., 1987. Personal communication.

Deb Ms received July 121990

\title{
SELOSTUS
}

\section{Eri menetelmillä luista erotetun lihan laatu ja varastointiolosuhteet}

\author{
L. Riihonen, J. Laine ja T. Kärkkäinen \\ Lihateollisuuden tutkimuskeskus \\ PL 56, SF-13101 Hämeenlinna, Suomi
}

Työssä tutkittiin mekaanisesti naudan ja sian luista erotetun lihan varastointiolosuhteita $+4^{\circ} \mathrm{C}$ lämpötilassa aina kuuden vuorokauden ja $-24^{\circ} \mathrm{C}$ lämpötilassa 140 vuorokauden säilytykseen asti. Tutkimuksessa olevat lihat erotettiin paineeseen perustuvalla Inject Star koneella (6 koesarjaa) ja kaavintaan perustuvalla Poss koneella (2 koesarjaa). Näytteet kerättiin puhtaalta koneelta ja pakat-

tiin välittömästi, analysointi suoritettiin tietyin văliajoin kemiallisfysikaalisesti ja mikrobiologisesti. Nautanăytteet säilyivät laadullisesti parempina kuin sikanäytteet niin kylmävarastoinnissa kuin pakkasvarastoinnissakin. Eri koneilta saaduilla näytteillä eroa $(\mathrm{P}<0.05)$ havaittiin tuhka, kalsium, fosfaatti, mikrobi ja kuiva-ainepitoisuuksissa. 